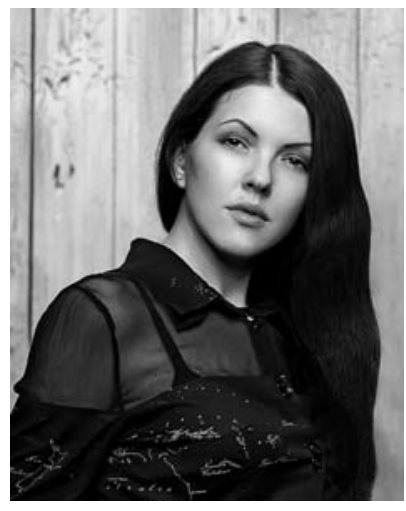

\title{
COPYRIGHT EXCEPTIONS AND LIMITATIONS IN THE EU-UKRAINE ASSOCIATION AGREEMENT ${ }^{*}$
}

\author{
Anna Shtefan \\ Head of Copyright and Related Rights Department \\ of Scientific-Research Institute of Intellectual Property, \\ $P h D$ in Law \\ ID ORCID: 0000-0003-2382-4849
}

The article deals with the analysis of copyright exceptions and limitations in the EUUkraine Association Agreement and the procedure for their application. The principles of the free use of works are analyzed; an explanation of how to separate the provisions of the Association Agreement that are directly applicable and not directly applicable is given. The limitations on the fixation right, broadcasting and communication to the public, distribution right, reproduction right and exceptions related to computer programmes and databases are investigated. Conclusions on provisions of the Association Agreement which should be implemented into domestic law have been made.

Keywords: copyright exceptions and limitations, free use of works, Association Agreement

Introduction. Copyright in its modern form seeks to balance the interests of the author and society. One of the legal mechanisms for achieving this goal is the establishment of exceptions and limitations in the author's monopoly on the use of works. Exceptions and limitations are cases where work can be used without the permission of the author and, as a rule, without payment of remuneration.

As explained in the doctrine, limitations typically protect freedom of expression and the right to privacy; they safeguard free competition, promote the dissemination of knowledge, or respond to symptoms of market failure [1, 64]. The possibility of free use of works is provided to satisfy the most important social interests. Copyright should not interfere with the cultural, spiritual, intellectual development of society; exceptions and limita- tions are needed for the development of science, education, and culture, as well as serving public and private interests. At the same time, the rights and interests of the author or another right holder should not be suffering. In other words, the free use of the work should not affect the possibility of using the work by the author or another right holder.

Principles of free use of works are enshrined in Art. 9 (2) of the Berne Convention for the Protection of Literary and Artistic Works [2] according to which it shall be a matter for domestic legislation in the state parties to permit the reproduction of such works in certain special cases, provided that such reproduction does not conflict with a normal 'exploitation' of the work and does not unreasonably prejudice the legitimate interests of the author. This provision contains three

\footnotetext{
* Стаття друкується в авторській редакції.
} 
basic requirements that the free use of works should satisfy:

1) the free use of a work should be restricted to certain special cases. The scope and limits of the free use of works are not determined accidentally nor at one's individual discretion, but are envisaged by the law that establishes a clear list of cases when such use is permissible and lawful;

2) the free use of a work should not conf lict with its normal use. The use of $t$ he work by the copyright holder and the free use of the work by third part ies must be carried out in different $\mathrm{w}$ ays. There should be no competition between the author or other copyrigh $\mathrm{t}$ holder and third parties regarding use the work;

3) the free use of a work should not unre asonable prejudice the legitimate int erests of the author. Only extremely important public interests may ou tweigh the copyright and require suc $\mathrm{h}$ free use of the work when this wou ld harm the interests of the author. However, as a general rule, the free use of a work should not give rise to any obstacles to or other negative eff ects on the possibility of the exploita tion of the work by the author. An au thor may not be deprived of the possi bility of obtaining economic benefitfrom the use of their work for the re ason that the benefit is already recei ved by another person acting within the limits of copyright [3, 21-22].

These principles are integrated into the EU when providing copyright exceptions and limitations. They are also contained in Art. 172 (3), 175(3) of Association Agreement between the European Union and its Member States, of the one part, and Ukraine, of the other part [4] (the Association Agreement) which state that the Parties may provide for exceptions and limitations to only in certain special cases which do not conflict with normal exploitation of the work or other subject-matter and do not unreasonably prejudice the legitimate interests of the right holder.

The Association Agreement mentions only a few copyright exceptions and limitations while in the EU and in Ukraine, the law also contains others. However, some of the cases of the free use of works covered by the Association Agreement are not yet established in Ukrainian law.

The Association Agreement is the part of the national legislation and is applied in the same manner as foreseen for the rules of the national legislation. However, it is important to note that the Association Agreement contains two types of rules: rules that apply directly and rules that do not apply directly. The rule that applies directly contains a clear and precise provision, certain rights and obligations, permits or prohibitions, that is, acts as a direct regulator of public relations. Such a rule is characterized by the lack of guidance on any procedure that must be carried out by the state in order for the rule to become applicable [5, 7]. Rules that do not apply directly do not impose rights or obligations but indicate that a state may provide for such rights or obligations in its domestic law. That is, such a rule will take effect only after the state provides for it in national law.

As one of the obligations of Ukraine is to bring copyright law in line with European legislation, it is necessary to examine the features of the exceptions and limitations in the Association Agreement and draw conclusions as to how these exceptions and limitations should be applied.

Limitations on the fixation right, broadcasting and communication to the public, and distribution right. The Association Agreement in Art. 172 (1) allows Parties to provide for limitations of mentioned rights in respect of:

a) private use.

The Directive 2001/29/EC on the harmonization of certain aspects of copyright and related rights in the informa- 
tion society [6] (the InfoSoc Directive) specifies this rule in more details. According to Art. 5 (2) (b) Member States may provide for exceptions or limitations to the reproduction right in respect of reproductions on any medium made by a natural person for private use and for ends that are neither directly nor indirectly commercial, on condition that the right holders receive fair compensation which takes account of the application or non-application of technological measures referred to in Article 6 to the work or subject-matter concerned.

Thus, this copyright exception is characterized by such signs:

- it can only be carried out by a natural person;

- it does not cover collective use;

- it cannot be carried out in the field of commercial activity or any other activity related to the receipt of profits;

- right holders should be paid a fair remuneration.

Law of Ukraine "On Copyright and Related Rights» [7] regulates this exception in Art. 25. First, it allows reproduction exclusively for personal purposes or for the circle of the family of legally published works except for

a) works of architecture in the form of buildings;

b) computer programs, except for cases stipulated by Art. 24;

c) reprographic reproduction of books, musical notes and original works of fine art except for the cases stipulated by Art. 22 and 23.

Such reproduction is carrying out without the permission of the author (or another right holder) and without royalty payment. Second, this provision allows home reproduction of works and performances recorded in phonograms and videograms, as well as audiovisual works and their copies exclusively for personal purposes or for the family circle without the permission of the author (s), performers, producers of phonograms, producers of videograms but with the payment of remuneration to them.
That is, private use as a copyright exception is fully regulated by the domestic legislation of Ukraine;

b) use of short excerpts in connection with the reporting of current events.

This exception comes from Art. 10bis (2) of the Berne Convention which establishes that it shall be a matter for legislation in the countries of the Union to determine the conditions under which, for the purpose of reporting current events by means of photography, cinematography, broadcasting or communication to the public by wire, literary or artistic works seen or heard in the course of the event may, to the extent justified by the informatory purpose, be reproduced and made available to the public.

In addition to this the InfoSoc Directive in Art. 5(3)(c) provides for the reproduction by the press, communication to the public or making available of published articles on current economic, political or religious topics or of broadcast works or other subject-matter of the same character, in cases where such use is not expressly reserved, and as long as the source, including the author's name, is indicated, or use of works or other subject-matter in connection with the reporting of current events, to the extent justified by the informatory purpose and as long as the source, including the author's name, is indicated, unless this turns out to be impossible.

The existence of such an exception is necessary to ensure the dissemination of information. In order to inform the public about events taking place in different countries of the world, the media should be able to freely use the works that are located in places where certain events occur, as well as to reproduce and distribute works on current economic, political or religious topics.

In Ukrainian Law «On Copyright and Related Rights», there are two rules which allow free use of works by media.

First, according to Art. 21(3) it is permitted to reproduce, public perfor- 
mance or broadcast of previously published articles in newspapers or journals on current economic, political, religious or social issues or publicly announced works of the same nature in cases where the right to such reproduction, public performance or other communication to the public is not specifically prohibited by the author. This provision covers the social topics of works which are not provided by the Berne Convention. Also, it allows the authors to prohibit the use of their works by the media but the law does not specify how such a warning should be made. When it comes to the article, it is advisable to place a warning about the prohibition with the text of the article which will enable interested parties to know about the existence of a forbiddance. In the case of oral works, such a prohibition may be communicated directly when making speeches, lectures, etc.

Second, Art. 21(4) states the possibility of reproduction in order to highlight current events by means of photographs or cinematographs, broadcasting or other public announcements of works seen or heard during the course of such events to the extent justified by an informational purpose. In other words, the legislation permits the use of works in reports, articles, and other materials devoted to the coverage of events during which these works were seen or heard.

Therefore, the use of short excerpts in connection with the reporting of current events is provided by Ukrainian law;

c) ephemeral fixation by a broadcasting organisation by means of its own facilities and for its own broadcasts.

This provision is based on Art. 5(2)(d) of the InfoSoc Directive in accordance to which the Member States may provide for exceptions or limitations to the reproduction right in respect of ephemeral recordings of works made by broadcasting organisations by means of their own facilities and for their own broadcasts; the preservation of these recordings in official archives may, on the grounds of their exceptional documentary character.

Law of Ukraine "On Copyright and Related Rights» does not hold this exception the reproduction right although in this context the provisions of Art. 48 (4) of Law of Ukraine "On Television and Radio Broadcasting» [8] is interesting. All programs that the television organization broadcasts or retransmits or provides their broadcast or retransmission in complete and unaltered form by a third party (telecommunications operator) must be recorded and stored within 14 days from the date of distribution if no complaints regarding their content have been received within this period.

That is, the recording of any program should be carried out and kept for at least 14 days from the date of distribution regardless of whether the program is a documentary nature and whether any work is reproduced within this program. This requirement is primarily aimed at ensuring the possibility of refuting inaccurate information and protection of honour, dignity and business reputation. Since the Association Agreement in Art. 172 (1) states "Parties may provide..." this indicates that this rule does not act directly. However, in the light of European integration processes, it is necessary to investigate the need for implementation of this exception to the right to reproduce in the domestic copyright legislation;

d) use solely for the purposes of teaching or scientific research.

In international and European law, there are several provisions for this exception.

First, in Art. 10 (2) of the Berne Convention it is proposed to allow the free use of works to permit the utilization, to the extent justified by the purpose, of literary or artistic works by way of illustration in publications, broadcasts or sound or visual recordings for teaching, provided such utilization is compatible with fair practice. The InfoSoc Directive in Art. 5 (3) (a) regulates this rule a bit dif- 
АВТОРСЬКЕ ПРАВО ТА СУМІЖНІ ПРАВА

ferently allowing the use for the sole purpose of illustration for teaching or scientific research, as long as the source, including the author's name, is indicated, unless this turns out to be impossible and to the extent justified by the noncommercial purpose to be achieved. The Berne Convention does not mention the exclusively non-commercial purpose of such use; here it is indicated the fair practice of the use. As provided in Art. 10(3) of the Berne Convention, where use is made of works in accordance with the preceding paragraphs of this Article, mention shall be made of the source, and of the name of the author if it appears thereon. Art. 21(2) of Law of Ukraine "On Copyright and Related Rights" in this part is similar to the provisions of the Berne Convention: it is allowed to use literary and artistic works to the extent justified by the intended purpose, as illustrations in publications, broadcasting, sound recordings or video recordings of educational character. Mandatory designation of the author's name and source of borrowing is the common rule of free use of works in Ukraine; however, Ukrainian law does not require that the purpose of the use of works for teaching must be exclusively non-profit.

Second, the Berne Convention in Art. 10 (1) and the InfoSoc Directive in Art. 5 (3) (d) provide for the free use of works by quoting. This exception is contained in Art. 21(1) of Law of Ukraine "On Copyright and Related Rights». Citation rules are characterized by the following features:

- the use of short fragments of works;

- the use has a critical, polemical, scientific or informational character;

- the work that is quoted must be lawfully made available to the public;

- the author's name and the source of borrowing must be indicated unless this turns out to be impossible.

In addition, Law of Ukraine "On Copyright and Related Rights» contains a separate article 23 dedicated to the free reproduction of works for study. Thus, the copyright exception relating to the free use of works for the purposes of teaching or scientific research in the Ukrainian legislation is regulated in full.

Exceptions and limitations on the reproduction right. According to Art. 175 (1) of the Association Agreement the Parties shall provide that temporary acts of reproduction referred to in Article 173 (Reproduction right) of this Agreement, which are transient or incidental, which are an integral and essential part of a technological process and the sole purpose of which is to enable: (a) transmission in a network between third parties by an intermediary; or (b) lawful use of a work or other subject-matter to be made, and which have no independent economic significance, shall be exempted from the reproduction right provided for in Article 173.

This provision was first established in the InfoSoc Directive and the application of this rule is limited by certain criteria. As CJEU specified, under Art. 5(1) of InfoSoc Directive, an act of reproduction may be exempted from the reproduction right provided for in Article 2 thereof only if it satisfies five conditions, that is, where

- the act is temporary;

- it is transient or incidental;

- it is an integral and essential part of a technological process;

- the sole purpose of that process is to enable a transmission in a network between third parties by an intermediary or a lawful use of a work or protected subject matter; and

- that act does not have any independent economic significance (paragraph 60) [9].

CJEU summarized that, as a rule, temporary acts of reproduction, on a multimedia player such as that at issue in the main proceedings, of copyright-protected works obtained from streaming websites belonging to third parties offering those works without the consent of the copyright holders are such as to adversely affect the normal exploitation of 
those works and causes unreasonable prejudice to the legitimate interests of the right holder (paragraph 70) [9].

Therefore, temporary acts of reproduction under Art. 5(1) of InfoSoc Directive do not cover streaming from websites or other cases when the reproduction is not a coincidence but the purpose and when it is carried out for the obtaining commercial gain.

Where the Parties provide for an exception or limitation to the right of reproduction provided for in Article 173, they may provide similarly for an exception or limitation to the right of distribution provided for in Article 171(1) of this Agreement to the extent justified by the purpose of the authorised act of reproduction (Art. 175(2) of the Association Agreement). This suggestion is quite logical because if a temporary reproduction is allowed, the person who implements it should be able to distribute the relevant object within the limits and the purpose related to the temporary reproduction.

In the Ukrainian legislation, such exceptions are not yet established. The rules of Art. 175(1)(2) of the Association Agreement can't be applied directly since the wording "the Parties shall provide...» and "where the Parties provide for ... they may provide..." indicates the need to establish these rules in the domestic law.

Exceptions related to computer programmes. The Association Agreement contains two articles that provide for cases where certain actions regarding computer programmes can be carried out without the permission of the right holder. These provisions are derived from the articles 5 and 6 of the Directive 2009/24/EC of the European Parliament and of the Council of 23 April 2009 on the legal protection of computer programs [10].

According to Art. 183(1) of the Association Agreement in the absence of specific contractual provisions, the following acts:

- permanent or temporary reproduction of a computer programme by any means and in any form, in part or in whole, acts of loading, display- ing, running, transmission or storage of the computer programme necessitate such reproduction;

- the translation, adaptation, arrangement and any other alteration of a computer programme and the reproduction of the results thereof, without prejudice to the rights of the person who alters the programme do not require authorisation by the right holder, where they are necessary for the use of the computer program by the lawful acquirer in accordance with its intended purpose, including for error correction.

The technical features of using a computer programme require it to be reproduced on the device of the person who purchased the programme or a license to use it. Use of the programme is impossible without its loading and running. That is why any act necessary for the use of a programme performed in accordance with its intended purpose should be carried out without the need for additional permission. The legal acquisition of a computer programme is a sufficient basis for its further use in accordance with its purpose. If a programme contains some errors, their fix cannot be forbidden, as it is necessary for its use. The translation, adaptation or any other transformation of the form of the code may be needed to obtain the information to achieve the interoperability of a programme with other programmes. However, such use of a programme should not be used in a way which prejudices the legitimate interests of the right holder.

It is stated in Art. 183(2) of the Association Agreement that the making of a back-up copy by a person having a right to use the computer programme may not be prevented by contract insofar as it is necessary for that use. This exception is conditioned by the need for normal exploitation of the computer programme.

Art. 183(3) of the Association Agreement provides that the person having a right to use a copy of a computer programme shall be entitled, without the 
АВТОРСЬКЕ ПРАВО ТА СУМІЖНI ПРАВА

authorisation of the right holder, to observe, study or test the functioning of the programme in order to determine the ideas and principles which underlie any element of the programme if such person does so while performing any of the acts of loading, displaying, running, transmitting or storing the programme which he or she is entitled to do. For effective use of computer programme it is necessary to know its functionality, features of execution of certain operations, the conditions and the order of achieving the necessary results. The legislation allows the free use of the computer programme for the purpose of observing, checking, studying its work to the extent that it is necessary for the use of the programme.

Art. 184 of the Association Agreement is devoted to a decompilation as reproduction of the programme's code and translation of its form. According to Art. 184(1) when these acts are indispensable to obtain the information necessary to achieve the interoperability of an independently created computer programme with other programmes, they do not require the authorisation of the right holder if the following conditions are met:

(a) these acts are performed by the licensee or by another person having a right to use a copy of a programme, or on their behalf by a person authorised to do so;

(b) the information necessary to achieve interoperability has not previously been readily available to the persons referred to in subparagraph (a) of this paragraph; and

(c) these acts are confined to the parts of the original programme which are necessary to achieve interoperability.

Decompilation has a very narrow scope and is clearly limited to its purpose. Art. 184(2) expressly forbids the following use of information obtained within decompilation:

(a) to be used for goals other than to achieve the interoperability of the independently created computer programme; (b) to be given to others, except when necessary for the interoperability of the independently created computer programme; or

(c) to be used for the development, production or marketing of a computer programme substantially similar in its expression, or for any other act which infringes copyright.

In addition, in accordance with the provisions of the Berne Convention, Art. 184 may not be interpreted in such a way as to allow its application to be used in a manner which unreasonably prejudices the right holder's legitimate interests or conflicts with a normal exploitation of the computer programme (Art. 184(3). Thus, exceptions related to computer programmes are very specific and do not allow any use that may harm the interests of right holders.

In Law of Ukraine "On Copyright and Related Rights» there is Art. 24 that contains substantively similar rules. The difference with the Association Agreement is that the Ukrainian law allows the computer programme to be decompiled by a person who legitimately owns a computer programme that is legitimately made, while the Association Agreement uses the term "the licensee or by another person having a right to use a copy of a programme». This difference is very significant because, as is well known, software developers nowadays do not sell computer programmes but mostly sell licenses for their use. That is, the Association Agreement covers both those who have purchased the programme and the licensees. Ukrainian law only indicates ownership of the programme which may mean that only buyers have the right to decompile while such a right is not granted to licensees.

However, the narrower scope of Art. 24 of Law of Ukraine «On Copyright and Related Rights» do not create a problem. Rules of Art. 184 of the Association Agreement, as well as rules of Art. 183, formulated in such a way as to be direct- 
ly applicable, their application does not require these provisions to be reflected in national law. Therefore, exceptions related to computer programmes can be applied in Ukraine as provided for in the Association Agreement.

Exceptions related to databases. The Association Agreement establishes the same exceptions for the databases provided for in Art. 6 of the Directive 96/9/EC of the European Parliament and of the Council of 11 March 1996 on the legal protection of databases [11].

As follows from Art. 188 and Art. 189(1) of the Association Agreement, a performance by the lawful user of a database or a copy thereof of any of these acts:

(a) temporary or permanent reproduction by any means and in any form, in whole or in part;

(b) translation, adaptation, arrangement and any other alteration;

(c) any form of distribution to the public of the database or copies thereof;

(d) any communication, display or performance to the public;

(e) any reproduction, distribution, communication, display or performance to the public of the results of the acts referred to in subparagraph (b)

which is necessary for purposes of access to the contents of the database and normal use of the contents by the lawful user shall not require the authorisation of the author of the database. Where the lawful user is authorised to use only part of the database, this provision shall apply only to that part.

The need for this rule is explained by the fact that a legitimate user of the database or its copy must be able to access and use the content that the database is filled with. Such an opportunity must be granted without obtaining a separate authorisation, without any agreement with the author of the database. It is interesting to note that the Directive 96/9/EC and the Association Agreement use the term «author of the database» while not only the author but also another person may be the right holder of a database.
According to Art. 189(2) of the Association Agreement the Parties shall have the option of providing for limitations on the above rights in the following cases:

(a) in the case of reproduction for private purposes of a non-electronic database;

(b) where there is use for the sole purpose of illustration for teaching or scientific research, as long as the source is indicated and to the extent justified by the non-commercial purpose to be achieved;

(c) where there is use for purposes of public security or for the purposes of an administrative or judicial procedure;

(d) where other exceptions to copyright are traditionally authorised by each Party, without prejudice to subparagraphs (a), (b) and (c).

As stated in Art. 189(3) in accordance with the Berne Convention, this Article may not be interpreted in such a way as to allow its application in a manner which unreasonably prejudices the right holder's legitimate interests or conflicts with normal exploitation of the database.

Law of Ukraine «On Copyright and Related Rights» does not provide for separate exceptions for databases. Although clauses (b) and (c) of Art. 189(2) of the Association Agreement are contained in Ukrainian law as general copyright exceptions; there is no rule that permits reproduction for private purposes of a non-electronic database. Art. 189(1) of the Association Agreement can be applied without any additional measures as it is formulated as a clear rule that provides for specific rights. The provisions of Art. 189(2)(a) is formulated in such a way that "the Parties shall have the option of providing for limitations...» which makes it impossible to apply this rule directly. That is, to apply this rule it should be incorporated into the domestic legislation of Ukraine.

Conclusion. Copyright exceptions and limitations have been transposed into the Association Agreement from several EU directives; i.e. there are no rules in these 
provisions that would be new to the EU. A considerable part of these provisions is also inscribed in Law of Ukraine «On Copyright and Related Rights» but at the same time, some of them are absent in the legislation of Ukraine.

Certain rules may apply directly from the Association Agreement, in other words, their application does not require to be implemented in the domestic law of Ukraine. However, a few important copyright exceptions cannot be applied directly because the relevant provisions of the Association Agreement are formulated so that Ukraine has the right to introduce those exceptions. This means that until these exceptions are incorporated into the domestic legislation, they will not apply in Ukraine. Taking into account that Ukraine is not obliged to introduce these exceptions into national law, it is necessary to investigate in more detail these exceptions and the practice of their application, as well as possible problems that arise in connection with these exceptions. This will make suggestions as to how such exceptions should be formulated in the legislation of Ukraine which may become a subject for future research.

\section{Список використаних джерел / List of references}

1. Guibault L. Evaluating Directive 2001/29/EC in the Light of the Digital Public Domain. The Digital Public Domain: Foundations for an Open Culture. Cambridge: Open Book Publishers, 2012. P. 61-79.

2. Berne Convention for the Protection of Literary and Artistic Works.

URL: https://www.wipo.int/treaties/en/text.jsp?file_id=283698.

3. Shtefan A. Freedom of Panorama: The EU Experience. European Journal of Legal Studies. 2019. Vol. II No. 2. P. 13-27.

4. Association Agreement between the European Union and its Member States, of the one part, and Ukraine, of the other part. URL: https://eur-lex.europa.eu/legalcontent $/ E N / A L L /$ ? uri $=C E L E X \% 3 A 22014 A 0529 \% 2801 \% 29$.

5. Shtefan A. Some issues of application of the Association Agreement as the source of copyright of Ukraine. Theory and practice of intellectual property. 2019. № 1 . P. 5-16. (Штеббан А. Деякі проблели застосування Угоди про асоиіацію як джерела авторського права Украӥни. Теорія і практика інтелектуальної власності. 2019. № 1. C. 5-16).

6. Directive $2001 / 29 / E C$ on the harmonization of certain aspects of copyright and related rights in the information society. URL: https://eur-lex.europa.eu/legalcontent $/$ EN/TXT/? uri=CELEX\%3A32001L0029.

7. Law of Ukraine «On Copyright and Related Rights».

URL: https: / /zakon.rada.gov.ua/laws/show/3792-12.

8. Law of Ukraine "On Television and Radio Broadcasting».

URL: https: //zakon.rada.gov.ua/laws/show/3759-12.

9. Judgment of the Court (Second Chamber), 26 April 2017, Stichting Brein v Jack Frederik Wullems. Case C 527/15. ECLI:EU:C:2017:300. URL: http: / / curia.europa.eu/juris /document/document.jsf;jsessionid=9ea7d0f130d60 7e02d40280c42f8a4afe798d63ed4ce.e34KaxiLc3eQc40LaxqMbN4Pax4Se0?text=\& docid $=190142 \&$ pageInde $=0 \&$ doclang $=E N \&$ mode $=$ lst $\&$ dir $=\& o c c=$ first $\&$ part $=1 \&$ cid $=865460$.

10.Directive 2009/24/EC of the European Parliament and of the Council of 23 April 2009 on the legal protection of computer programs. URL: https://eurlex.europa.eu/legal-content /EN/TXT/PDF/?uri=CELEX:32009L0024\&from=EN.

11. Directive 96/9/EC of the European Parliament and of the Council of 11 March 1996 on the legal protection of databases. URL: https://eur-lex.europa.eu/legalcontent $/ E N / T X T / P D F /$ ? uri=CELEX:31996L0009\&from=EN. 
Штефан А. Исключения и ограничения авторского права в Соглашении об ассоциации между ЕС и Украиной. В статье рассмотрены исключения и ограничения авторского права в Соглашении об ассоциации между ЕС и Украиной и порядок их применения. Исследованы принципы свободного использования произведений, проанализированы исключения из права на воспроизведение, эфирное вещание и доведение до всеобщего сведения, распространение, а также исключения, касающиеся компьютерных программ и баз данных.

Ключевые слова: исключения и ограничения авторского права, свободное использование произведений, Соглашение об ассоциации

Штефан А. Винятки та обмеження авторського права в Угоді про асоціацію між СС та Україною. Винятки й обмеження майнових авторських прав $е$ одним з механізмів балансування інтересів автора і суспільства. Можливість вільного використання творів необхідна для задоволення найважливіших соціальних потреб та інтересів, культурного, духовного, інтелектуального розвитку суспільства, якому не повинно перешкоджати авторське право. Водночас, права автора мають забезпечуватися гарантією нормального використання твору при його вільному використанні. Для додержання співвідношення між інтересами автора і суспільства застосовуеться триступеневий тест Бернської конвенщії, на основі якого визначається можливість встановлення конкретних винятків з майнових прав автора.

Положення Угоди про асоціацію, присвячені виняткам і обмеженням, містять дві групи норм: ті, що застосовуються безпосередньо, i ті, застосування яких потребуе встановлення відповідних правил у внутрішньому законодавстві. Внаслідок аналізу цих положень, а також норм Законів України «Про авторське право і суміжні права», «Про телебачення і радіомовлення» було зроблено висновки, що:

- ряд винятків та обмежень, передбачених Угодою про асоціацію, врегульовані також у внутрішньому законодавстві України. До них належать ті, що надаються для використання творів в особистих цілях, з навчальною чи науковою метою, для висвітлення перебігу поточних подій засобами масової інформації;

- деякі винятки та обмеження, зазначені в Угоді про асоціацію, не містяться у внутрішньому законодавстві України, проте можуть застосовуватися безпосередньо з Угоди про асоціацію. До них відносяться винятки, що стосуються комп’ютерних програм. Вони частково відображені у нормах Закону України «Про авторське право і суміжні права», однак Угода про асоціацію містить й деякі інші положення, які є нормами прямої дії та підлягають застосуванню без відповідного уточнення норм внутрішнього законодавства;

- частина винятків та обмежень, встановлених Угодою про асоціацію, внутрішнім законодавством України не передбачена, а для їх застосування необхідне внесення відповідних змін і доповнень у норми внутрішнього законодавства, оскільки відповідні норми Угоди про асоціацію не $е$ нормами прямої дії. Такими винятками $е$ поодиноке відтворення творів організацією мовлення за допомогою своїх власних засобів і для своїх власних передач мовлення; тимчасове відтворення, яке має поодинокий характер і є складовою й суттевою частиною технологічного процесу; винятки, пов'язані з використанням баз даних.

Щодо останньої групи винятків й обмежень слід враховувати, що Україна не зобов'язана впроваджувати їх у національне законодавство, а тому необхідно більш детально дослідити ці винятки та практику їх застосування.

Ключові слова: виключення та обмеження авторських прав, безкоштовне використання творів, Угода про асоціацію 